\title{
Hydrogeochemical characteristics of central Jianghan Plain, China
}

\author{
Yu Zhou $\cdot$ Yanxin Wang $\cdot$ Yilian Li $\cdot$ \\ François Zwahlen $\cdot$ Julie Boillat
}

Received: 16 July 2010/ Accepted: 12 June 2012/Published online: 17 July 2012

(C) Springer-Verlag 2012

\begin{abstract}
The central Jianghan Plain is the semi-closed basin in the middle reaches of Yangtze River. A total of 78 water samples targeting groundwater were collected from 75 sites in this study site, the area between Yangtze River and Han River, including rivers and lakes for temperature, $\mathrm{pH}$, electrical conductivity (EC), total dissolved solids (TDS) and ion composition measurements. Correlation matrix was used to assess the geochemical and anthropogenic processes. The most confined groundwater was grouped into $\mathrm{HCO}_{3}-\mathrm{Ca}-\mathrm{Mg}$, while phreatic groundwater and surface water had a more diversified hydrochemistry. The spatial variation in overall water quality as well as comparison with WHO (World Health Organization) standards for drinking water is illustrated. Mn, As and $\mathrm{NO}_{3}{ }^{-}$concentrations were found to exceed the allowable limits for drinking water of WHO guidelines, and they also show remarkable spatial variations. Abnormally high nitrate concentration, up to $150-190 \mathrm{mg} / \mathrm{l}$, was found only in phreatic groundwater, which suggested that the nitrate pollution might be caused by agricultural activities. The present study may be helpful in further studies concerning water quality issues in this area where groundwater is a vital source for drinking and other activities.
\end{abstract}

Keywords Jianghan Plain - Groundwater . Hydrochemistry $\cdot$ Nitrate

Y. Zhou $(\bowtie) \cdot$ Y. Wang · Y. Li

School of Environmental Studies and MOE Key Laboratory

of Biogeology and Environmental Geology,

China University of Geosciences, Wuhan, China

e-mail: zhouyu19840208@gmail.com

Y. Zhou · F. Zwahlen · J. Boillat

Center of Hydrogeology, University of Neuchatel,

2000 Neuchatel, Switzerland

\section{Introduction}

Water quality has been rapidly declining worldwide, particularly in developing countries due to natural and anthropogenic processes (Carpenter et al. 1998; Chen et al. 2002). The geochemical characteristics of groundwater are the result of the combined action of different factors. They are closely related to the geological environment and hydro-meteorological condition of the area, groundwater recharge, flow and discharge as well as human activities.

Jianghan Plain is a semi-closed basin in the middle reaches of the Yangtze River. Scant attention has been paid to the deteriorating quality of groundwater in Jianghan Plain despite its use for drinking and other activities. The earliest study on major ion chemistry of the Han River was reported by $\mathrm{Hu}$ et al. (1982), but with a low sampling frequency at few stations. Chen et al. (2002) studied the water chemistry of the Yangtze River and its tributaries, including the Han River, and reported a significant increasing trend in $\mathrm{SO}_{4}{ }^{2-}$ concentrations in the Yangtze River due to anthropogenic factors. However, the study only had data from 11 sites on the main channel of the upper Han River, which was hardly sufficient for characterizing the major ion chemistry of the vast Jianghan Plain. The waters in the upper Han River basin are of the $\mathrm{Ca}-\mathrm{HCO}_{3}$ type with low mineralization and moderate alkalinity. $\mathrm{COD}_{\mathrm{Mn}}$ and nitrogen compounds are the main pollutants impairing water quality of the basin $(\mathrm{Li}$ et al. 2009). However, any study on the middle reaches of Han River has been rarely reported. Since poor investigation has been done in the study area, Jianghan Plain, it is necessary to conduct groundwater reconnaissance sampling to know the basic relevant physical-chemical characteristics. This research was performed as a case study to characterize the hydrochemistry of central Jianghan Plain, which featured 
groundwater, the main source of local drinking water supply, in comparison to surface water like rain, lake water and water from Han River or its tributary, Dongjing River. The results of this investigation are of direct importance to the local residents.

\section{Site description}

Meteorological and topographic characteristics

Low, flat and crisscrossed by rivers and lakes, Jianghan Plain is the major farming area of Hubei Province in center China, the well-known "national base of fish and rice" in China. Alluvial sediments were deposited by rivers and lakes formed by meandering of Yangtze River and Han River. The upper Han River is the water source area of China's South-to-North Water Transfer Project which will transfer water to North China including Beijing and Tianjin for domestic, industrial and irrigational usages ( $\mathrm{Li}$ et al. 2009). The climate is warm and humid in Jianghan Plain with plenty of precipitation. The average annual precipitation is $1,269 \mathrm{~mm}$, increasing from $800 \mathrm{~mm}$ in the northwest to $1,500 \mathrm{~mm}$ or more in the southeast, with $30-50 \%$ of it concentrated in summer. The terrain is smooth, full of rivers, lakes, fluviolacustrine permeable and water-bearing loose sand and sandy gravel, so Jianghan
Plain is characterized by sufficient groundwater recharge, shallow burial depth and so on. The altitude range in the Central Plain is $40-30 \mathrm{~m}$ in the northwest and $27-20 \mathrm{~m}$ in the southeast, and the lowest zone is $20 \mathrm{~m}$.

\section{Geomorphic features}

The geomorphology of the Jianghan Plain can be grouped into two categories, the hilly and plain area to the boundaries and low plain areas at the center (Fig. 1). The former was formed earlier and usually suffered from erosion; it shows the shape of wave, and the second terrace composed of upper Pleistocene series $\left(\mathrm{Q}_{3}\right)$ is very flat with a slope angle of $2-3^{\circ}$. The ravines are wide and shallow and the slope angles of the valley side are usually $<5^{\circ}$. However, the high terrace composed of mid-Pleistocene series $\left(\mathrm{Q}_{2}\right)$ shows a wavy shape in dissected topography with a depth of 40-60 m. Locally outcropped bedrocks sometimes present a big slope angle of $5-8^{\circ}$. The latter is the very vast central lower plain with a slope of $1 / 20,000-1 / 30,000$ and decreases from west to east.

\section{Regional hydrogeological condition}

The lithology of the Jianghan Plain is mainly Quaternary deposit; the hydrogeological characteristics are closely correlated to the topography. The hilly area consists

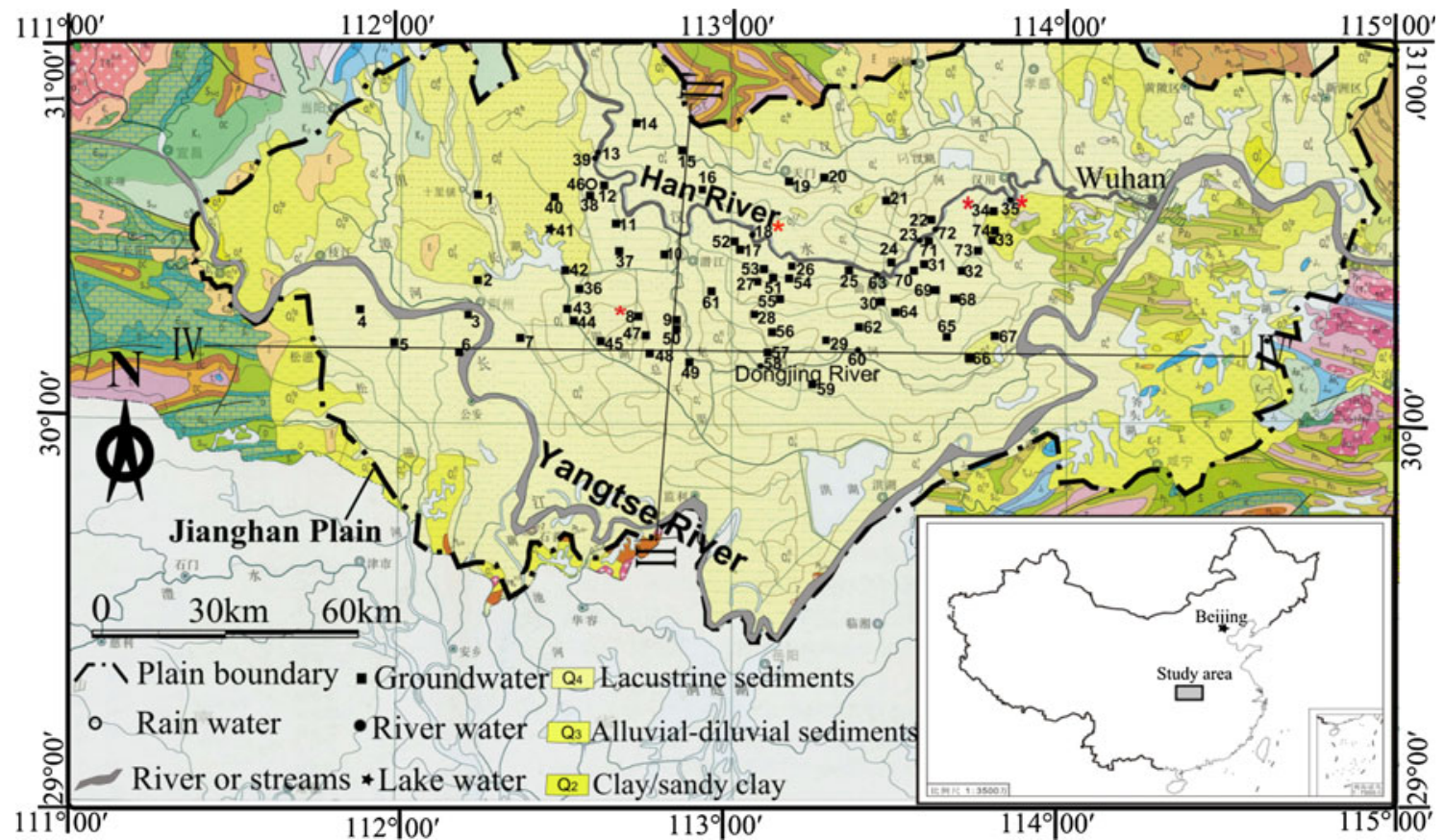

Fig. 1 Map of sampling locations in the study area. (13, 18, 23, 35, 39, 63 and 72 from Han River; 58 and 60 from Dongjing River; 7, 9, $10,17,14,34,37,42,51,57,73,52,53,59$ and 71 from shallow phreatic aquifer with well depths ranging from 4 to $8 \mathrm{~m}$, others from confined aquifer with well depths ranging from 15 to $40 \mathrm{~m}$ ). Mark asterisk stands for samples were collected respectively at the same site in both year 2007 and 2008 


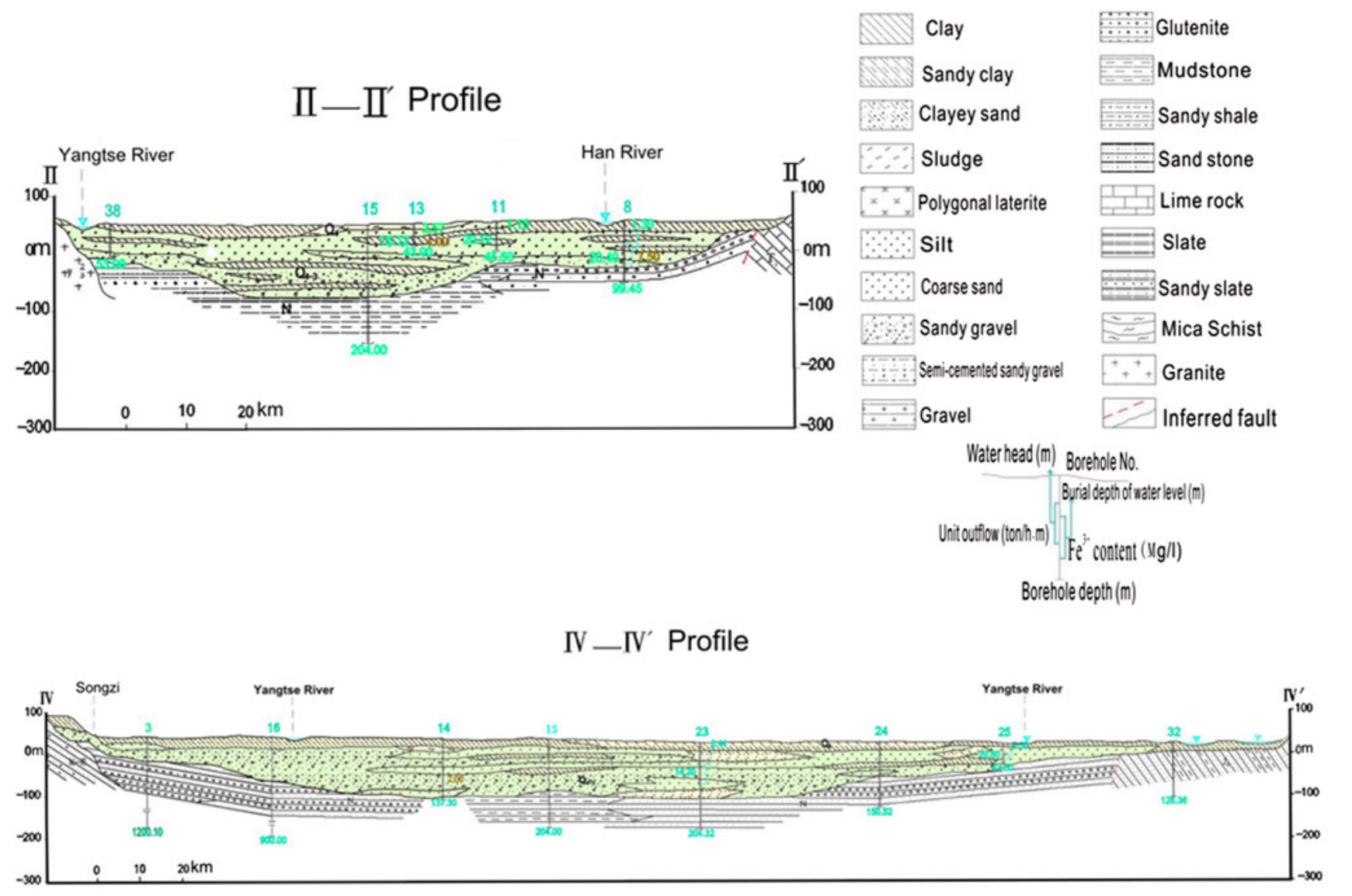

Fig. 2 Hydrogeological profiles of Fig. 1. Translated and adapted from Hubei hydrogeology team (1976)

primarily of aquitard while the center is of unconsolidated water-bearing sediment layer, constituting a complete hydrogeological unit, an enclosed basin; Quaternary unconsolidated sediments form porous media and Pliocene clasolite forms porous-fissure media for groundwater (Fig. 2). The aquifer system can be grouped into vadose water, phreatic water and confined groundwater based on burial condition. Shallow pore water in the unconsolidated matrix is the key target of this research. The study area is located mostly in this central lower plain of Holocene series $\left(\mathrm{Q}_{4}\right)$ and the groundwater almost stays still since the slope is extremely small. Head gradients commence at the hilly areas from northwest toward southeast, with a very low hydraulic gradient in the interior central part of the plain.

\section{Sampling and methods}

Water samples from variable depths were collected for the analyses of major constituents and their spatio-temporal behavior. Groundwater samples include Quaternary Holocene phreatic water (depth of water table, $0.5-2 \mathrm{~m}$ ) and shallow confined groundwater (burial depth, 10-40 m) at various locations viz. hand pumps, open wells and tube wells. Currently, the wells in the area are used for extracting groundwater from its aquifer for the supply of freshwater. A total of 78 water samples were collected from 75 sites in center Jianghan Plain, the area between Yangtse River and Han River, including rivers and lakes (Fig. 1). Field surveys were conducted in June 2007 with 35 water samples (from No.1 to No. 35) and August 2008 with 43 water samples (from No.36 to No.74 and also No.8, $18,34,35$ for the second time). Surface water samples including 11 river samples, 1 rain sample and 1 lake sample were collected; the latter two were taken for comparison with each other and to indicate the potential hydraulic connection, though two samples may not be very representative. Samples from wells were collected after pumping for at least $20 \mathrm{~min}$ prior to sampling. River and lake samples were taken around $20 \mathrm{~m}$ to the riverside/ lakeside at a depth of $50 \mathrm{~cm}$ under the surface.

All the water samples were sampled using previously acid-washed high-density polyethylene (HDPE) $500 \mathrm{ml}$ bottles. The water samples for inorganic analysis were filtered $(0.45 \mu \mathrm{m}$ Millipore nitrocellulose filter) in the field 
and a small portion of these samples was stored for measuring anions, while another portion was acidified with ultrapure $\mathrm{HNO}_{3}{ }^{-}$to $\mathrm{pH}<2$ for cation determination. They were stored at $4{ }^{\circ} \mathrm{C}$ in HDPE bottles prior to analysis in the laboratory. Before sampling, wells were purged until field parameter measurements became stable. Water temperature, $\mathrm{pH}$, electrical conductivity (EC) and total dissolved solids (TDS) were measured in situ using portable instruments, Hach sension2 and Hach LDOTM HQ10, which had been calibrated before use. The $\mathrm{HCO}_{3}{ }^{-}$was determined by titration with $\mathrm{HCl}$ on the day of sampling. Major cations $(\mathrm{Na}, \mathrm{K}, \mathrm{Ca}$ and $\mathrm{Mg}$ ) and other trace elements were determined using inductively coupled plasma atomic emission spectrometry (ICP-AES) (IRIS Intrepid II XSP DUO, USA). Anions $\left(\mathrm{Cl}^{-}, \mathrm{NO}_{3}{ }^{-}\right.$and $\left.\mathrm{SO}_{4}{ }^{2-}\right)$ were measured using a Dionex Ion Chromatograph (IC) (Dionex Corporation, Sunnyvale, CA, USA). All chemical parameters were analyzed in the water quality laboratory of the Key Laboratory of Bio-geology and Environmental Geology, China University of Geosciences, Wuhan, China. All groundwater chemistry results were within $5 \%$ of ionic charge balance.

Pearson correlation was carried out to evaluate the relationships between various physiochemical parameters, with statistical significance set at $p<0.05$. All the processes were performed using SPSS 13.0.

\section{Results and discussion}

Chemical data analysis of the physiochemical parameters

Besides the results shown in Tables 1, 2, B, Cd, Co Cr, Cu, $\mathrm{Li}, \mathrm{Mo}, \mathrm{Ni}, \mathrm{Pb}$ and Se concentrations were below detection limit or very low (data not shown). Surface waters are weak alkaline; $\mathrm{pH}$ of Han River water is from 7.12 to 8.07, with an average value of 7.8 , while rain water is an exception with a $\mathrm{pH}$ value of 6.36. However, $\mathrm{pH}$ of groundwater has a wider range, varying from slightly acidic (6.90) to slightly alkaline (7.58), mostly alkaline, and no distinct groupings were observed. The $\mathrm{pH}$ value of water is controlled by the amount of dissolved $\mathrm{CO}_{2}$, carbonate and bicarbonate concentrations. From the point of view of human consumption, all the samples may be considered potable, as they are neither acidic nor strongly alkaline.

Shallow confined groundwater has the highest average values for most of the attributes. Variations of the electrical conductivity (EC: $571-1173 \mu \mathrm{S} / \mathrm{cm}$ ) of the groundwater and low EC values in surface water $(283-344 \mu \mathrm{S} / \mathrm{cm})$ indicate that in summer the groundwater recharge by the river is quite intense, and the salinity depends on the influence of different local surface waters and hydraulic conductivity, including precipitation. The electrical conductivity with $400 \mu \mathrm{s} / \mathrm{cm}$ at $25{ }^{\circ} \mathrm{C}$ is considered suitable for human consumption (WHO 1994), while more than $1,500 \mu \mathrm{mhos} / \mathrm{cm}$ at $25{ }^{\circ} \mathrm{C}$ may cause corrosion of iron structures.

Calcium $(\mathrm{Ca})$ and magnesium $(\mathrm{Mg})$ are the most abundant cations in all the waters, with average concentrations of 42.86 and $10.52 \mathrm{mg} / \mathrm{l}$, respectively (Tables 1,2). Ca and $\mathrm{Mg}$ are major cations in water and relatively related to the natural conditions, mainly to dissolution processes of carbonate minerals. The occurrence and level of concentration of $\mathrm{Ca}$ and $\mathrm{Mg}$ in the groundwater are controlled by the base rocks or sediment deposits. Similarly, $\mathrm{Ca}$ is the dominant cationic contribution from calcareous soils. Herein, Ca/ $\mathrm{Mg}$ mol ratio is around two for most of the samples, which indicates that the water-rock interaction has eluted more calcite minerals. Sodium is the least abundant major cation with an average concentration of $5.1 \mathrm{mg} / \mathrm{l}$, and it could also have been added to the system through various anthropogenic activities.

Bicarbonate is the most abundant major anion, with an average of $119.3 \mathrm{mg} / \mathrm{l}$. The second most abundant anion is $\mathrm{SO}_{4}{ }^{2-}$ with an average concentration of $44.7 \mathrm{mg} / \mathrm{l}$; an agricultural source of $\mathrm{SO}_{4}$ is possible, e.g., $\mathrm{SO}_{4}$ fertilizer, sulfide mineral oxidation or a combination of these sources. The mean concentrations of $\mathrm{Cl}^{-}$and $\mathrm{NO}_{3}{ }^{-}$are below $10 \mathrm{mg} / \mathrm{l}$. Among the river waters, No. 58 and No. 60 were samples from Dongjing River, the tributary of Han River. They did not show much difference from other river samples, but all the samples from year 2008 had slightly lower values in almost all the variables than those from year 2007, even for those sampled at the same site. With regard to groundwater, samples from deeper wells displayed lower temperatures $\left(<20^{\circ}\right)$ and those sampled in summer at the same depth showed a little higher value of temperature $\left(21-25^{\circ}\right)$. Surface water has higher temperature than groundwater in summer. Lake water has very similar features in all compositions as river water. Rain water has the lowest values for all the variables, except $\mathrm{Zn}$ of $3.25 \mathrm{mg} / \mathrm{l}$.

From Table 2, it can be seen that all the river waters from different locations of Han River are just slightly different in all characteristics, which implies that there is no serious point-source pollution along the stream, i.e., no local contamination by wastewater, sewage systems or draining. They have lower TDS from 135 to $197 \mathrm{mg} / \mathrm{l}$ and low mineralization, as shown by the EC measurements, varying from 283 to $344 \mu \mathrm{s} / \mathrm{cm}$. The $\mathrm{HCO}_{3}{ }^{-}$concentration ranged from 101.6 to $139.58 \mathrm{mg} / \mathrm{l}$, and $\mathrm{Cl}^{-}$from 3.61 to $15.54 \mathrm{mg} / \mathrm{l}$. Shallow confined groundwater is characterized by a high degree of variability with respect to most variables, $\mathrm{pH}$ from $6.65-7.67$, EC $387-1,144 \mu \mathrm{S} / \mathrm{cm}, \mathrm{HCO}_{3}{ }^{-}$ $234.01-832.16 \mathrm{mg} / \mathrm{l}, \mathrm{Cl}^{-}$nd (not detected) $\sim 91.82 \mathrm{mg} / \mathrm{l}$, 
Table 1 Chemical data statistics: main variables (T, pH, TDS, EC), ion compositions

\begin{tabular}{|c|c|c|c|c|c|c|c|c|}
\hline & \multicolumn{4}{|c|}{ Shallow phreatic groundwater $(n=16)$} & \multicolumn{4}{|c|}{ Shallow confined groundwater $(n=49)$} \\
\hline & Average & Max & Min & STD & Average & Max & Min & STD \\
\hline $\mathrm{Ag}$ & 0.48 & 0.55 & 0.41 & 0.10 & 0.98 & 1.40 & 0.55 & 0.60 \\
\hline As & 0.03 & 0.04 & 0.02 & 0.01 & 0.06 & 0.13 & 0.02 & 0.03 \\
\hline $\mathrm{Ba}$ & 0.32 & 0.70 & 0.08 & 0.16 & 0.34 & 0.83 & 0.02 & 0.18 \\
\hline $\mathrm{Ca}$ & 125.82 & 173.50 & 45.67 & 36.78 & 94.79 & 142.10 & 48.18 & 23.74 \\
\hline $\mathrm{Fe}$ & 0.11 & 0.45 & 0.01 & 0.14 & 6.95 & 37.77 & 0.01 & 9.63 \\
\hline $\mathrm{K}$ & 15.50 & 75.14 & 0.89 & 22.01 & 1.07 & 3.05 & 0.09 & 0.70 \\
\hline $\mathrm{Mg}$ & 39.45 & 64.01 & 19.30 & 14.49 & 29.32 & 66.35 & 12.50 & 12.05 \\
\hline $\mathrm{Mn}$ & 0.65 & 3.11 & 0.00 & 0.99 & 0.34 & 2.37 & 0.00 & 0.37 \\
\hline $\mathrm{Na}$ & 24.66 & 56.26 & 9.03 & 15.34 & 13.60 & 26.45 & 5.64 & 5.28 \\
\hline $\mathrm{P}$ & 0.16 & 1.05 & 0.00 & 0.28 & 0.47 & 3.24 & 0.00 & 0.73 \\
\hline $\mathrm{S}$ & 27.90 & 42.80 & 12.50 & 10.17 & 1.09 & 15.41 & 0.04 & 3.34 \\
\hline $\mathrm{Sb}$ & 0.50 & 1.13 & 0.05 & 0.46 & 0.64 & 0.69 & 0.59 & 0.07 \\
\hline $\mathrm{Si}$ & 13.53 & 24.74 & 5.78 & 5.80 & 19.33 & 37.36 & 8.38 & 8.11 \\
\hline $\mathrm{Sr}$ & 0.66 & 1.03 & 0.32 & 0.21 & 0.48 & 1.48 & 0.28 & 0.18 \\
\hline V & 0.19 & 0.29 & 0.12 & 0.06 & 0.14 & 0.26 & 0.07 & 0.05 \\
\hline $\mathrm{Zn}$ & 0.03 & 0.24 & 0.00 & 0.07 & 0.05 & 0.49 & 0.00 & 0.09 \\
\hline $\mathrm{F}$ & 0.31 & 0.74 & 0.02 & 0.17 & 0.33 & 0.97 & 0.08 & 0.17 \\
\hline $\mathrm{Cl}$ & 68.97 & 162.06 & 9.93 & 43.71 & 8.76 & 91.82 & nd & 15.24 \\
\hline $\mathrm{NO}_{3}$ & 68.36 & 193.60 & nd & 64.55 & 1.93 & 14.63 & nd & 2.89 \\
\hline $\mathrm{H}_{2} \mathrm{PO}_{4}$ & 0.19 & 1.74 & nd & 0.52 & 0.61 & 9.68 & nd & 2.42 \\
\hline $\mathrm{SO}_{4}$ & 96.34 & 178.01 & 16.87 & 50.17 & 3.26 & 30.55 & nd & 5.97 \\
\hline $\mathrm{HCO} 3$ & 406.60 & 646.05 & 116.70 & 178.36 & 491.40 & 832.16 & 234.01 & 129.93 \\
\hline TDS (mg/l) & 598.04 & 886.00 & 277.00 & 197.94 & 397.92 & 654.39 & 242.00 & 102.00 \\
\hline Well depth (m) & 5.63 & 8.00 & 4.00 & 2.31 & 22.97 & 40.00 & 10.00 & 9.62 \\
\hline$T\left({ }^{\circ} \mathrm{C}\right)$ & 22.09 & 28.30 & 17.40 & 3.70 & 19.74 & 23.40 & 17.80 & 1.49 \\
\hline $\mathrm{pH}$ & 7.14 & 7.58 & 6.90 & 0.18 & 7.13 & 7.67 & 6.65 & 0.22 \\
\hline Ec $(\mu \mathrm{s} / \mathrm{cm})$ & $1,124.94$ & $1,773.00$ & 571.00 & 397.71 & 714.02 & $1,144.00$ & 387.00 & 198.80 \\
\hline
\end{tabular}

Unit in $\mathrm{mg} / \mathrm{l}$ except $T$ in ${ }^{\circ}, \mathrm{EC}$ in $\mu \mathrm{s} / \mathrm{cm}$, well depth in $\mathrm{m}$ and $\mathrm{pH}$

nd Not detected

$\mathrm{Mg}^{2+} 12.5-66.35 \mathrm{mg} / \mathrm{l}, \mathrm{Na}^{+} 5.64-26.45 \mathrm{mg} / \mathrm{l}$, TDS 242$654.39 \mathrm{mg} / \mathrm{l}, \mathrm{Ca}^{2+} 48.18-142.1 \mathrm{mg} / \mathrm{l}, \mathrm{NO}_{3}{ }^{-}$nd $\sim 14.63 \mathrm{mg} / \mathrm{l}$, and $\mathrm{SO}_{4}{ }^{2-}$ nd $\sim 30.55 \mathrm{mg} / \mathrm{l}$. Neither total mineralization nor major ion composition are clearly distinguishable between geographic groups. The high variation also reveals that the diffusion between phreatic groundwater and deep aquifer probably appears locally and surely also changes with the season.

\section{Spatial pattern of ions}

Geographical location and the environmental conditions play an important role in the hydrochemistry characteristics of the groundwater. There are several possible explanations for the variations in groundwater composition. Natural variations include the ionic input from rainwater, the chemical composition of the soil and processes occurring through the unsaturated zone. Other factors are due to human activity and include agriculture, water use or even saltwater intrusion when the equilibrium is disturbed at the contact between freshwater and saltwater. All the samples have been plotted onto Piper diagram (Fig. 3) and almost all of them were of the $\mathrm{HCO}_{3}-\mathrm{Ca}-\mathrm{Mg}$ type, clustering at the left corner of the diamond on the plot, which indicates a main control by rock weathering or soil leaching. Their TDS is less than $1 \mathrm{~g} / \mathrm{l}$, and this water type is characteristic of shallow zone. Close correspondence in major ion compositions is also consistent with the generally homogeneous hydrogeological condition shown in Fig. 2, Phreatic waters shift to the center, indicating a lower $\mathrm{HCO}_{3}{ }^{-}$concentration but higher $\mathrm{SO}_{4}{ }^{2-}$ concentration, due to the ion exchange with the surface water and dissolution reaction resulting from agricultural sources. 
Table 2 Chemical data statistics: main variables ( $\mathrm{T}, \mathrm{pH}$, TDS, EC), ion compositions

\begin{tabular}{|c|c|c|c|c|c|c|}
\hline \multirow[t]{2}{*}{ Term } & \multicolumn{4}{|c|}{ Han river water $(n=11)$} & \multirow[t]{2}{*}{ Lake water (JH6) } & \multirow[t]{2}{*}{ Rain water (JHR) } \\
\hline & Average & $\operatorname{Max}$ & Min & STD & & \\
\hline $\mathrm{Ag}$ & 1.12 & 1.12 & 1.12 & 0.00 & nd & nd \\
\hline As & 0.03 & 0.04 & 0.02 & 0.00 & 0.02 & 0.01 \\
\hline $\mathrm{Ba}$ & 0.17 & 0.19 & 0.15 & 0.01 & 0.23 & nd \\
\hline $\mathrm{Ca}$ & 42.86 & 50.46 & 36.69 & 5.40 & 36.59 & 1.89 \\
\hline $\mathrm{Fe}$ & 3.68 & 12.33 & 0.01 & 5.14 & 0.05 & 0.02 \\
\hline $\mathrm{K}$ & 1.94 & 3.21 & 1.23 & 0.76 & 2.49 & nd \\
\hline $\mathrm{Mg}$ & 10.52 & 13.49 & 8.85 & 1.94 & 11.48 & 0.15 \\
\hline Mn & 0.12 & 0.35 & nd & 0.16 & nd & 0.02 \\
\hline $\mathrm{Na}$ & 5.10 & 8.76 & 3.64 & 1.43 & 7.68 & 0.14 \\
\hline $\mathrm{P}$ & 0.13 & 0.39 & 0.04 & 0.12 & 0.00 & 0.02 \\
\hline $\mathrm{S}$ & 9.63 & 12.08 & 8.53 & 1.22 & 12.65 & 1.82 \\
\hline $\mathrm{Sb}$ & 0.31 & 0.46 & 0.16 & 0.10 & 0.55 & 0.66 \\
\hline $\mathrm{Si}$ & 5.52 & 6.60 & 0.30 & 1.82 & 5.68 & 0.32 \\
\hline $\mathrm{Sr}$ & 0.24 & 0.30 & 0.20 & 0.04 & 0.25 & 0.01 \\
\hline V & 0.05 & 0.06 & 0.03 & 0.01 & 0.06 & 0.02 \\
\hline $\mathrm{Zn}$ & 0.03 & 0.05 & 0.01 & 0.01 & 0.00 & 3.25 \\
\hline $\mathrm{F}$ & 0.40 & 0.63 & 0.20 & 0.11 & 0.52 & 0.07 \\
\hline $\mathrm{Cl}$ & 10.64 & 15.54 & 3.61 & 3.83 & 24.21 & 2.36 \\
\hline $\mathrm{NO}_{3}$ & 3.56 & 8.19 & 0.00 & 3.47 & 0.62 & 1.10 \\
\hline $\mathrm{H}_{2} \mathrm{PO}_{4}$ & nd & nd & nd & 0.00 & nd & nd \\
\hline $\mathrm{SO}_{4}$ & 34.79 & 44.80 & 9.26 & 9.84 & 44.04 & 7.14 \\
\hline $\mathrm{HCO} 3$ & 119.33 & 139.58 & 101.60 & 16.32 & 89.97 & 9.15 \\
\hline TDS (mg/l) & 166.34 & 197.25 & 135.60 & 24.07 & 157.90 & 10.40 \\
\hline$T\left({ }^{\circ} \mathrm{C}\right)$ & 26.20 & 28.50 & 22.80 & 2.39 & 26.40 & 22.30 \\
\hline $\mathrm{pH}$ & 7.80 & 8.07 & 7.12 & 0.27 & 7.47 & 6.36 \\
\hline $\mathrm{Ec}(\mu \mathrm{s} / \mathrm{cm})$ & 311.27 & 344.00 & 283.00 & 22.24 & 328.00 & 523.00 \\
\hline
\end{tabular}

Unit in $\mathrm{mg} / \mathrm{l}$ except $T$ in ${ }^{\circ} \mathrm{C}, \mathrm{EC}$ in $\mu \mathrm{s} / \mathrm{cm}$ and $\mathrm{pH}$

nd Not detected

It is observed that only in shallow phreatic groundwaters, the major ions exhibit noticeable spatial variations. Anion chemistry was not consistent, but calcium and magnesium were of dominant composition. In confined groundwater, calcium as the dominant cation contributes $42-70 \%$ of the major cation budget and $\mathrm{HCO}_{3}{ }^{-}$constitutes more than $90 \%$ of most of the samples. River water shows slight difference in ion composition as seen from the Piper diagram. Water composition is dominated by $\mathrm{HCO}_{3}{ }^{-}$ and $\mathrm{Ca}^{2+}$, including rain and lake water. Precipitation in winter is generally much less intense than in summer, so one heavy rainfall in summer could probably represent a significant proportion of the annual total precipitation. Calcium and magnesium together account to over $90 \%$ of the cations measured, while the sum of $\mathrm{HCO}_{3}{ }^{-}$and $\mathrm{SO}_{4}{ }^{2-}$ comprises $63-100 \%$ of the anions with few exceptions. River waters have quite low and consistent TDS (135.6-197.25 mg/l), lake water also has TDS in this range, but rain water displays the lowest TDS of $10.4 \mathrm{mg} / \mathrm{l}$. Both phreatic and confined groundwaters have very wide range of TDS, 277-886 $\mathrm{mg} / \mathrm{l}$ and $242-654 \mathrm{mg} / \mathrm{l}$, respectively. TDS values of $<500 \mathrm{mg} / \mathrm{l}$ are generally considered to be good. Drinking water becomes significantly unpalatable at TDS value $>1,000 \mathrm{mg} / \mathrm{l}$. From this point of view, therefore, groundwater quality meets the standards of drinking water. Basically, all waters from all the different aquatic environments are fresh water, which is consistent with the hydrogeological setting.

As, $\mathrm{Si}, \mathrm{Mn}, \mathrm{S}, \mathrm{Fe}$ and $\mathrm{NO}_{3}{ }^{-}$are six typical components showing spatial variation in this area (Fig. 4). Silica has lower concentration with a median value of $5.52 \mathrm{mg} / \mathrm{L}$ in river waters and it is lowest in rain water, while it reaches up to an average value of 13.53 and $19.33 \mathrm{mg} / \mathrm{l}$ in phreatic and confined groundwater, respectively. $\mathrm{Si}$ in water is in the form of its oxide, silica $\left(\mathrm{SiO}_{2}\right)$, or its hydrated form, $\mathrm{Si}(\mathrm{OH})_{4}$. Silica constitutes the bulk of common rocks, 
Fig. 3 Piper diagrams showing ion composition (symbol size proportional to TDS, $10.4-886 \mathrm{mg} / \mathrm{l}$ )

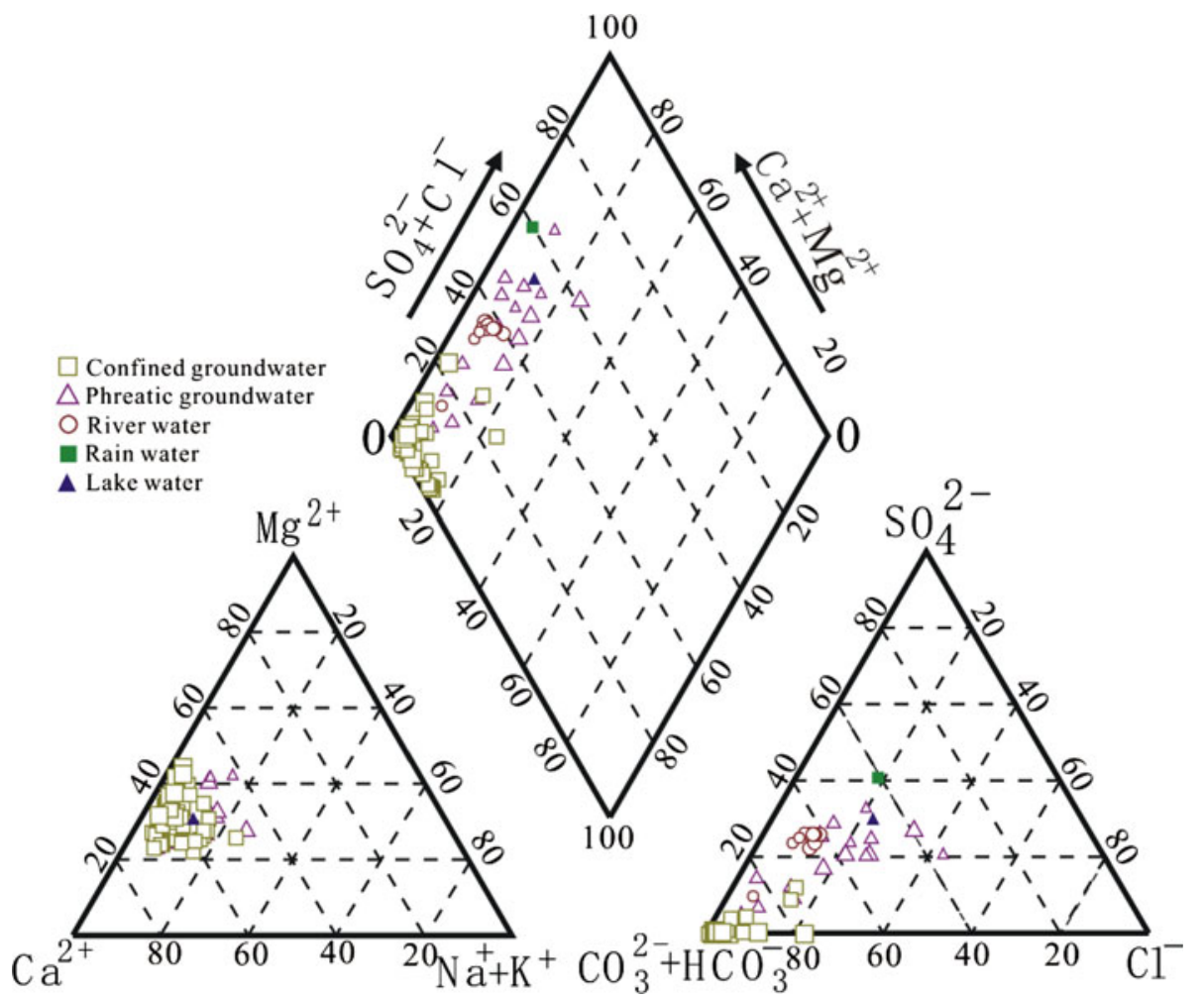

soils, clays and sands. Water that drain or interact with deposits high in silicate minerals normally contain high $\mathrm{Si}$ content. Fe and $\mathrm{S}$ concentrations show more obvious spatial variation, some around zero but some reaches more than $30 \mathrm{mg} / \mathrm{l}$, and there is no spatial relevance seen from the location of the high concentration samples. Fe in the groundwater is obtained from weathering process of minerals. Under reduction condition, ferric oxides and oxyhydroxides such as hematite $\left(\mathrm{Fe}_{2} \mathrm{O}_{3}\right)$ or goethite $(\mathrm{FeOOH})$ could possibly leach out as dissolved Fe. Most confined groundwater has high iron concentration, which indicates reducing environment, consistent with that indicated by the local people at No. 12. They said that the freshly pumped water had high turbidity and presented a light yellow color (implying high $\mathrm{Fe}$ concentration underground), so they used some sand to purify it by getting rid of the Fe colloids before drinking. Some river water samples have iron concentration of more than $10 \mathrm{mg} / \mathrm{l}$, but phreatic water and rain water have low concentrations, so the river must be polluted by wastewaters. The highest Fe and S occurrence was found in groundwater. The manganese (Mn) concentration above the WHO drinking standard, $0.5 \mathrm{mg} / \mathrm{l}$, was detected in groundwater, and the highest reached $3.11 \mathrm{mg} /$ 1. Sources of Mn occurrence could be from weathering process, where it can be in small amounts in carbonate solid solutions (Hem 1989). Abnormally high As and Mn concentrations are related to lithology, since they are quite often released from minerals, leached through soil and transferred into well water. Since the whole region is an agricultural area and has very little industry. As as a kind of anthropogenic induced pollutant can be ruled out. A more complete summary to explain the mechanism of As mobilization in groundwater was made by Mukherjee et al. (2009):

1. As is released by oxidation of As-bearing pyrite in the alluvial sediments (e.g., Mallick and Rajgopal 1995).

2. Arsenic anions sorbed to aquifer mineral grains are displaced into solution by competitive exchange of $\mathrm{PO}_{4}{ }^{3-}$ available from fertilizers of surface soils (Acharyya et al. 2000).

3. As sorbed to $\mathrm{FeOOH}(\mathrm{HFO})$ is released by reduction of solid phase $\mathrm{Fe}(\mathrm{III})$ coupled to oxidation of peat (Bhattacharya et al. 1997; Nickson et al. 1998, 2000; McArthur et al. 2001, 2004; Ravenscroft et al. 2001) or of dissolved organic carbon (DOC) (Harvey et al. 2002, 2005).

4. As is released from HFOs or other sediment phases by redox reactions related to $\mathrm{Fe}$ and $\mathrm{S}$ cycling (Zheng et al. 2004) and is retained in solution by partial redox equilibrium (Mukherjee et al. 2008). This proposed mechanism is a combination of mechanisms 1 (involving reoxidation of authigenic pyrite) and 3 . In addition to these views, many researchers have agreed that indiscriminate agricultural and industrial pumping may have facilitated the spread of As within groundwater 
Fig. 4 Contour maps of $\mathrm{Si}(5.80-24.7 \mathrm{mg} / \mathrm{l}), \mathrm{S}(0-42.8 \mathrm{mg} / \mathrm{l}), \mathrm{Mn}$ (0.005-3.11 mg/l), $\mathrm{NO}_{3}{ }^{-}(0-193.6 \mathrm{mg} / \mathrm{l})$, As $(0.016-0.130 \mathrm{mg} / \mathrm{l})$ and $\mathrm{Fe}(0.01-37.37 \mathrm{mg} / \mathrm{l})$ content in the study area. Those marked in red correspond to contour lines exceeding drinking water MCLs (WHO guideline, 1993) and samples with content exceeding the MCLs (Mn, $0.5 \mathrm{mg} / \mathrm{l} ; \mathrm{NO}_{3}{ }^{-}, 50 \mathrm{mg} / \mathrm{l} ; \mathrm{As}, 0.01 \mathrm{mg} / \mathrm{l}$ )

(Harvey et al. 2005). The presence of As in the groundwater seems to be derived from both natural and anthropogenic activities (mechanisms 4 and 2). This is coherently confirmed by the fact (Even et al. 2011) that vadose zone sediments contain up to $14.5 \mathrm{mg} / \mathrm{kg}$ As in the Jianghan Plain, especially in the eastern parts. Besides, reductive dissolution of iron and manganese oxides has also been identified (Even et al. 2011) as the mechanism that triggered As mobilization, and the persistence of As into groundwater is then enhanced by the inefficiency of the surrounding fine sediments to scavenge As.

Almost undetectable levels of $\mathrm{Mn}$ and $\mathrm{Fe}$ in rainfall and lake water show that atmospheric deposition does not contribute to observed concentrations in groundwater, confirming the geological cause. Abnormally high nitrate concentration, up to $150-190 \mathrm{mg} / \mathrm{l}$, was found only in phreatic groundwater, which suggested that the nitrate pollution might be caused by agricultural activities like fertilizer application. Besides, the study area is highly cultivated with very little urbanization or industry. High concentration of $\mathrm{NO}_{3}{ }^{-}$can cause birth malformation, hypertension, high-iron hemoglobin and goiter. Also, excessive loading of $\mathrm{NO}_{3}{ }^{-}$ contributes to river eutrophication (Carpenter et al. 1998). Actually, significant spatial variations of major ions of phreatic groundwater indicate the influence of surface water or precipitation, while confined groundwater shows uniformity due to uniform lithology. Studies have reported increasing nitrogen compound concentration and heavy metal contaminations in the Han River (Li et al. 2008, 2009; Liu et al. 2003; Chen et al. 2000). To maintain the quality of groundwater in those polluted regions, continuous monitoring of hydrochemistry should be done, and groundwater can be used for cooking and drinking only after treatment.

\section{Relationships between measured components}

Correlation coefficient is a commonly used measure to establish the relation between independent and dependent variables. Table 3 indicates the positive correlation among 15 parameters. $\mathrm{pH}$ shows negative correlation with all the other parameters. EC is a numerical expression of the ability of an aqueous solution to carry electric current. EC signifies the amount of TDS in water. The total dissolved solids (TDS) in drinking water reveal the saline behavior of

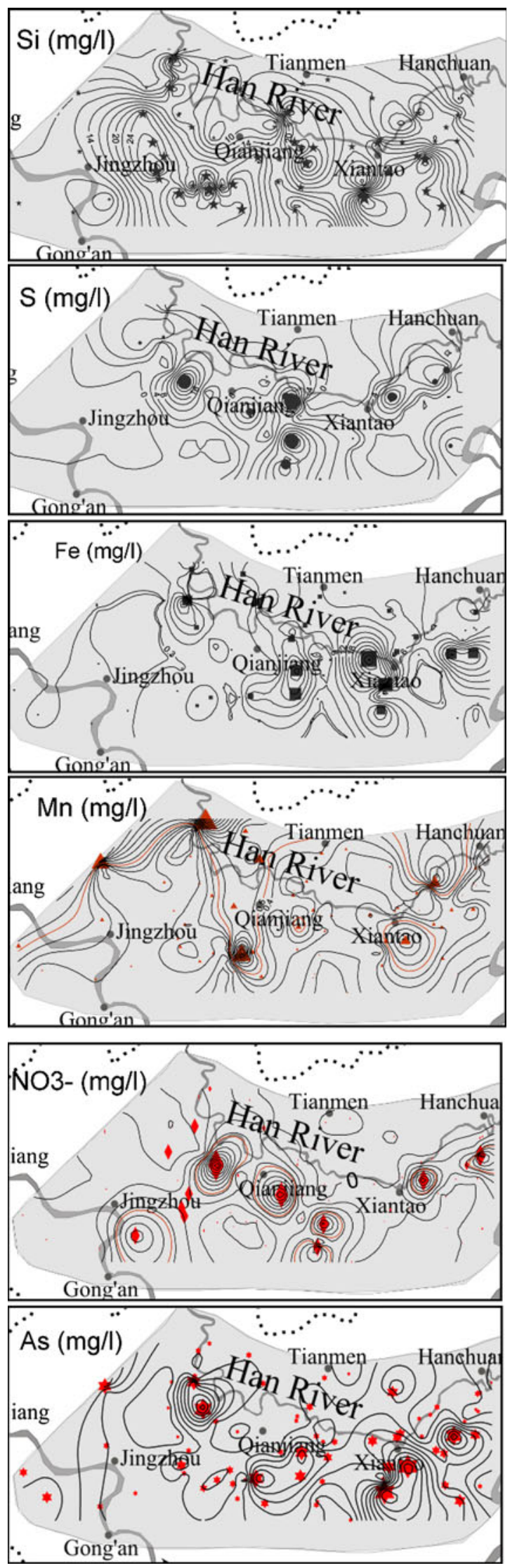




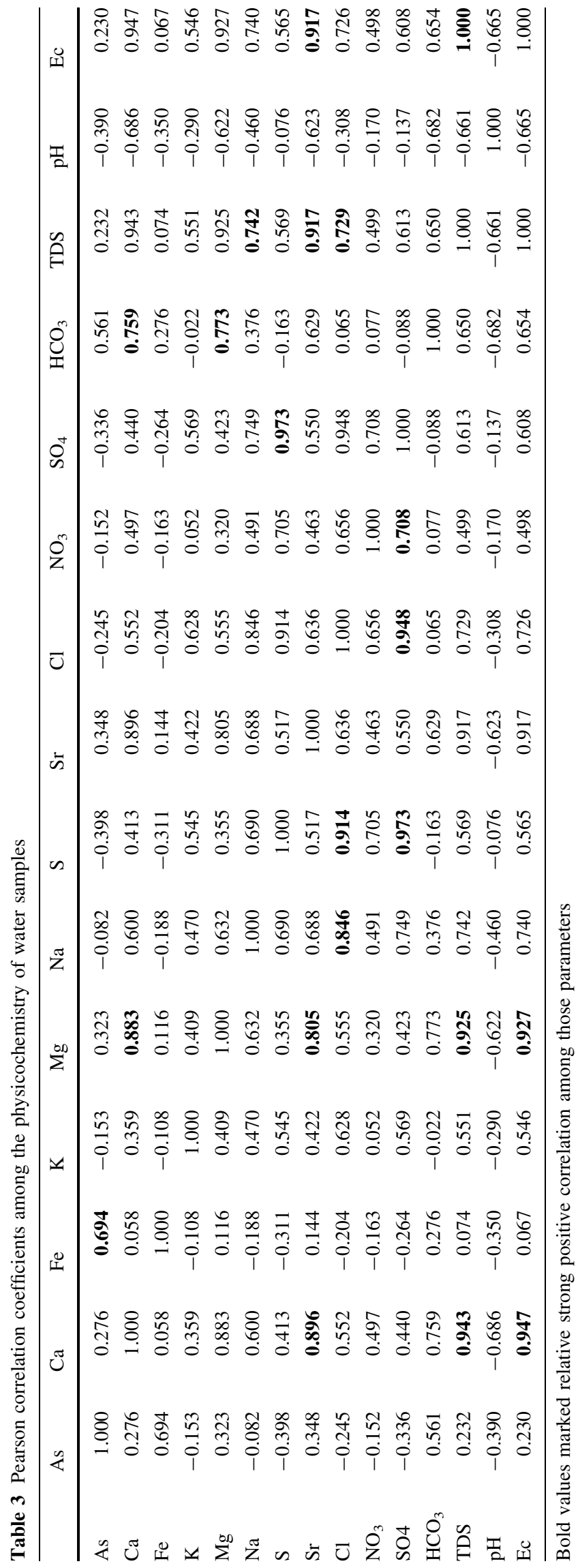

water. According to WHO (1996), TDS should be between 500 and $1,500 \mathrm{mg} / \mathrm{l}$. TDS was found to be within limit in most phreatic groundwater from shallow open wells, and lower in most confined groundwater samples and all surface water samples. Both $\mathrm{Ca}$ and $\mathrm{Mg}$ were highly positively correlated with EC and TDS; $\mathrm{Ca}$ and $\mathrm{Mg}(r=+0.883)$ also showed positive correlation, indicating a dissolution process with some $\mathrm{Ca}-\mathrm{Mg}$ carbonate aquifer matrix. In groundwater, hardness is mainly due to carbonates, bicarbonates, sulfates and chlorides of $\mathrm{Ca}$ and $\mathrm{Mg}$. In this study, $\mathrm{Ca}$ and $\mathrm{Mg}$ showed positive correlation with $\mathrm{HCO}_{3}{ }^{-}, r$ of 0.759 and 0.773 , respectively, suggesting that there was an increase in carbonate hardness paralleled by the increase in total hardness. This correlation points out that weathering of dolomites and the classic flysch deposits contributed to the basic ion water composition.

Total sulfur, sulfate and chloride positively correlated with each other. Besides $\mathrm{Ca}$ and $\mathrm{Mg}$, TDS also positively correlated with $\mathrm{Na}$ and $\mathrm{Cl}$, with $r$ of 0.742 and 0.729 , respectively. It was also noted that $\mathrm{Sr}$ showed positive correlation with $\mathrm{Ca}, \mathrm{Mg}, \mathrm{EC}$ and TDS, reflecting the evaporation of groundwater. The positive correlation between $\mathrm{Fe}$ and As, $r$ of 0.694 , indicated the release from the minerals of sediments, confirming the As release mechanism discussed above. This impact has been increasing recently, due to the increases in industrial and agricultural activities. Although most of the ionic contents on a basin-wide scale are within the permissible limits of drinking water standards, the abnormally high values of $\mathrm{NO}_{3}{ }^{-}$and $\mathrm{SO}_{4}{ }^{2-}$ in some of the phreatic groundwater samples are plausibly due to acid rains and agricultural activities. The rain water sample in this study with $\mathrm{pH}$ of 6.36 shows the strong acidity of rain, which is seen as a general global trend and increases with the global emissions of sulfur and nitrogen (Mackenzie 1998). The high levels of $\mathrm{SO}_{4}{ }^{2-}$ in water are also influenced by local fertilizers such as potassium sulfate. Besides, the study area has a very small slope gradient and has a base of Quaternary deposits, so it rules out the water flow path as a cause, i.e., higher concentrations of $\mathrm{SO}_{4}{ }^{2-}$ or $\mathrm{Cl}^{-}$on the lower reach of the water flow path.

Relative abundance of aqueous ionic species

A series of $\mathrm{X}-\mathrm{Y}$ plots (Fig. 5) has been attempted to assess relative abundances of major cationic and anionic species present in different water environments in the study area. The purpose is to decipher geochemical signatures of various processes the groundwater has been through for the acquisition of its chemical species and understand mutual affinities of various cations and anions present.

The major anions in groundwater, $\mathrm{HCO}_{3}$ and $\mathrm{Cl}$, have been plotted in Fig. 5a. The plot shows an overwhelming 
Fig. 5 a Relationship between $\mathrm{HCO}_{3}$ and $\mathrm{Cl}$. b Relationship between $\mathrm{Cl}$ and $\mathrm{SO}_{4}$. c Relationship between $\mathrm{Ca}+\mathrm{Mg}$ and $\mathrm{Na}+\mathrm{K}$. d Relative abundance of $\mathrm{HCO} 3$ and $\mathrm{Cl}+\mathrm{SO}_{4}$. e The $\mathrm{Ca}+\mathrm{Mg}$ versus $\mathrm{HCO}_{3}$ plot. f The $\mathrm{Na}+\mathrm{K}$ versus $\mathrm{Cl}$ plot. g Relationship between $\mathrm{SO}_{4}$ versus $\mathrm{Na}+\mathrm{K}$ plot. $\mathbf{h}$ The $\mathrm{Cl}$ versus $\mathrm{Na}$ plot. ( $g w$ stands for groundwater)
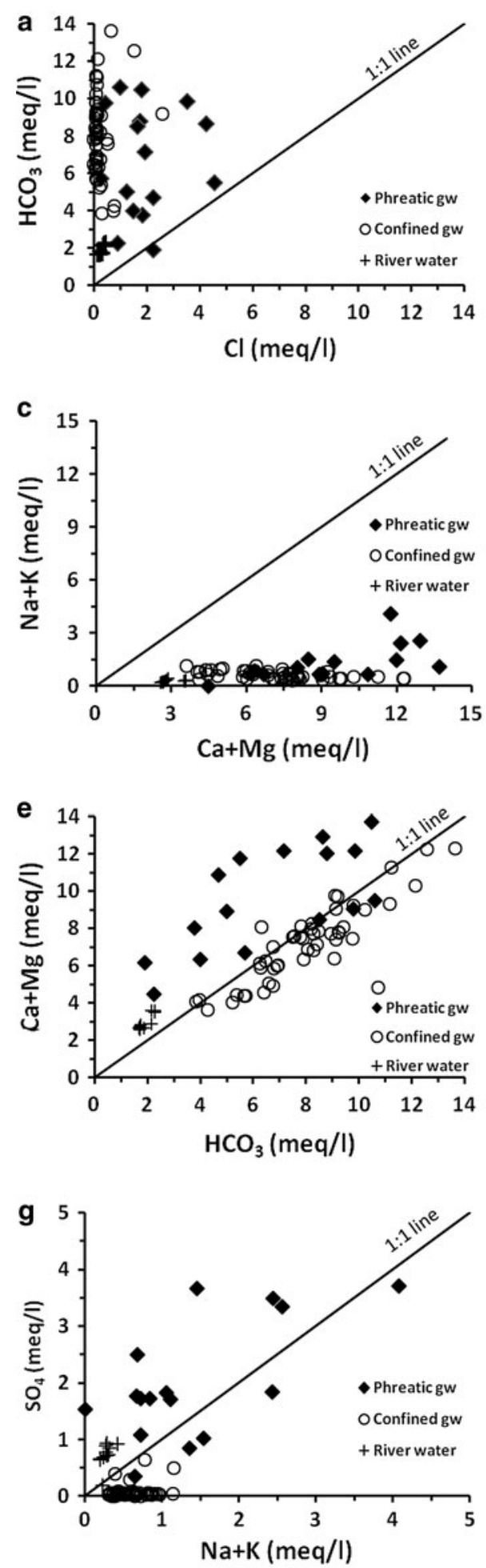
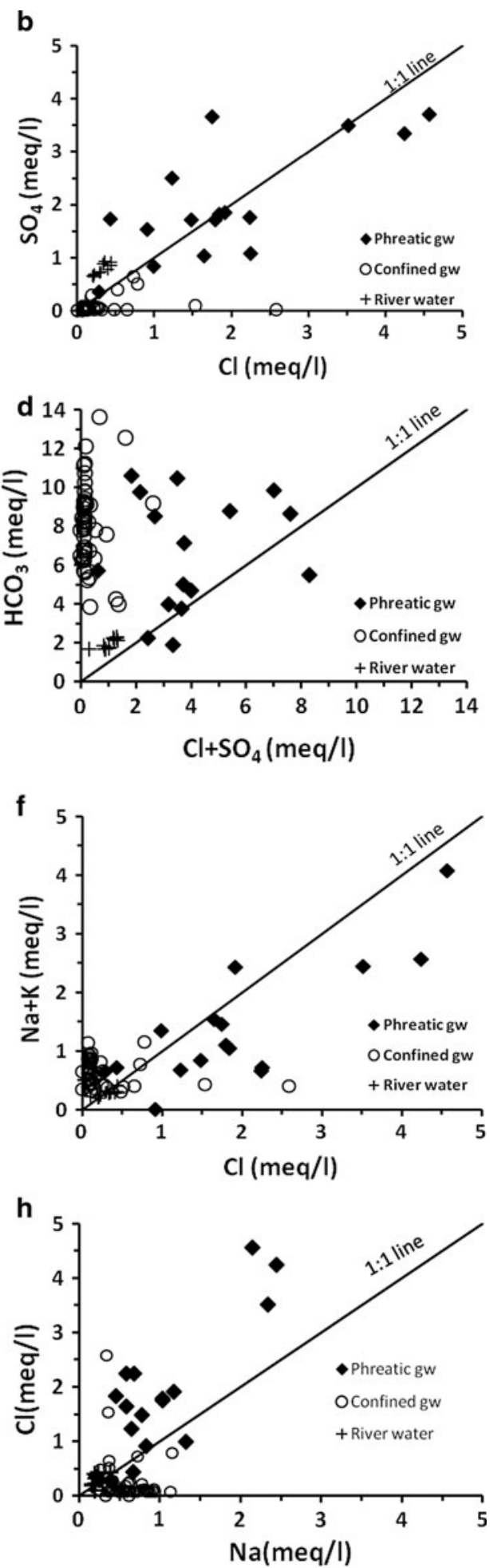

abundance of $\mathrm{HCO}_{3}$. Bicarbonate is indicated to be far more abundant than $\mathrm{Cl}$, and almost all the samples plot above the equal concentration (1:1) line. The inference that may be drawn here is that chemical species involving $\mathrm{HCO}_{3}$ such as bicarbonates of $\mathrm{Ca}, \mathrm{Mg}, \mathrm{Na}$ and $\mathrm{K}$ are likely to be far more abundant than chlorides of these cationic species.
The relative abundance of $\mathrm{Cl}$ and $\mathrm{SO}_{4}$ is depicted in Fig. 5b. Most confined groundwater samples and some samples of phreatic groundwater are below the equal concentration (1:1) line, suggesting the relative dominance of $\mathrm{Cl}$. The remaining samples, river water and some phreatic groundwater samples have $\mathrm{SO}_{4}>\mathrm{Cl}$. The 
Fig. 6 Piper diagram of analysis of groundwater samples collected by HEMS in 2006

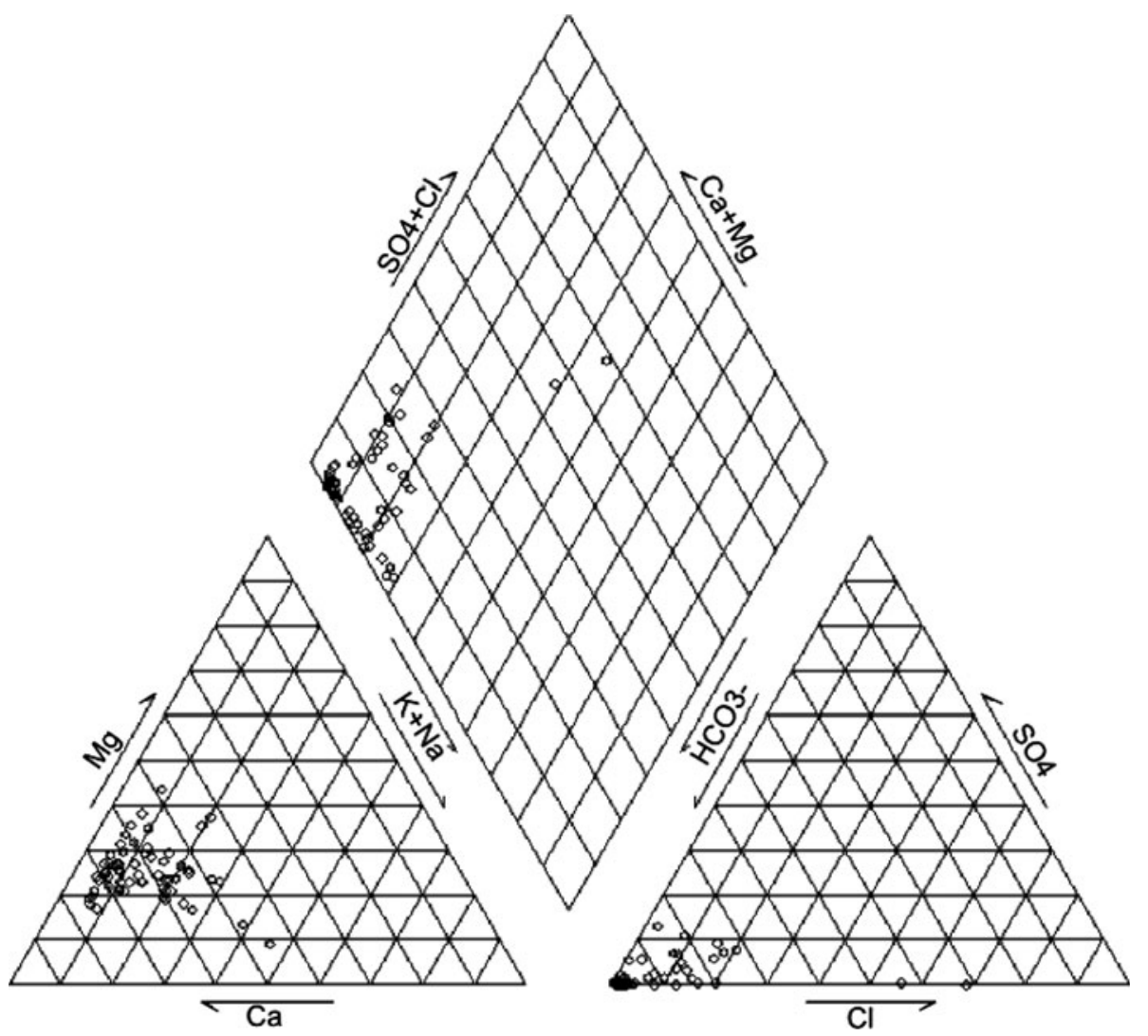

abundance of $\mathrm{SO}_{4}$ over $\mathrm{Cl}$ occurs in Han River, but not in specific zones in phreatic groundwater. Complex phreatic groundwater tends to suggest that a complex interaction of natural factors such as climatic influence, direction of groundwater flow and influent/effluent behavior of rivers, and anthropogenic impacts have been responsible for the observed distribution of $\mathrm{SO}_{4}$ and $\mathrm{Cl}$.

$\mathrm{Ca}+\mathrm{Mg}$ are relatively more abundant than alkalis among the major cations (Fig. 5c). The relative spatial consistency in the distribution of high $\mathrm{Ca}+\mathrm{Mg}$ values implies relative uniformity of processes responsible for acquisition of $\mathrm{Ca}+\mathrm{Mg}$ by groundwater in terms of geographical attributes.

As far as the geochemical characteristic of groundwater from the point of view anionic species is concerned, it is clearly a scenario of the abundance of $\mathrm{HCO}_{3}$, so much so that when plotted against the molar concentration of $\mathrm{Cl}+\mathrm{SO}_{4}$ (Fig. 5d), all river water and confined groundwater samples and more than $81 \%$ of the phreatic groundwater samples plot above the 1:1 line implying preponderance of $\mathrm{HCO}_{3}$ over $\mathrm{Cl}$ and $\mathrm{SO}_{4}$. While $\mathrm{HCO}_{3}$ may logically prefer to complex with $\mathrm{Ca}$ and $\mathrm{Mg}$ as implied in the occurrence of $\mathrm{Ca}-\mathrm{Mg}-\mathrm{HCO}_{3}$-type shallow groundwater in inland areas not significantly affected by anthropogenic influences, $\mathrm{Cl}$ may prefer to complex with alkalis, particularly, $\mathrm{Na}$. As far as $\mathrm{SO}_{4}$ species are concerned, they may, in all likelihood, be sulfates of $\mathrm{Ca}$ and $\mathrm{Na}$. To start with, the natural bonding affinity between $\mathrm{Ca}+\mathrm{Mg}$ and $\mathrm{HCO}_{3}$ needs to be evaluated (Fig. 5e). What emerges is that $>80 \%$ of the samples are right around the reference line, and most confined groundwater samples have slight excess of $\mathrm{HCO}_{3}$, i.e., there is leftover $\mathrm{HCO}_{3}$ after forming possible complexes with $\mathrm{Ca}$ and $\mathrm{Mg}$ available in the system. This, in turn, implies that $\mathrm{HCO}_{3}$ left after forming $\mathrm{Ca}$ and $\mathrm{Mg}$ species would be available for tying up with other cations such as $\mathrm{Na}$ and $\mathrm{K}$. River water and more than $80 \%$ of phreatic groundwater samples falling above the equivalent concentration line (Fig. 5e) have leftover $\mathrm{Ca}$ and $\mathrm{Mg}$ after the formation their bicarbonate species. $\mathrm{Ca}$ and $\mathrm{Mg}$, in all likelihood, may be incorporated in complexes such as sulfates and chlorides. Therefore, a small amount of species like $\mathrm{Na}-\mathrm{HCO}_{3}$ and $\mathrm{Ca}-\mathrm{Mg}-\mathrm{SO}_{4}$, in addition to more common ones such as $\mathrm{Ca}-\mathrm{HCO}_{3}$ and $\mathrm{Mg}-\mathrm{HCO}_{3}$, may be present in the groundwater of the study area.

With a view to assess bonding affinities of alkalis and $\mathrm{Cl}$, their equivalent concentrations have been plotted against one another (Fig. 5f). In general, there seems to be no apparent trend of enrichment on either side. As $\mathrm{Cl}$ would normally prefer to be associated with alkalis, rather than $\mathrm{Ca}$ and $\mathrm{Mg}$, it may be inferred that $\mathrm{Cl}$ has been consumed in forming alkali chlorides. This implies that for most confined groundwater, there would be no $\mathrm{Cl}$ available 
after the formation of $\mathrm{Na}-\mathrm{Cl}$ and $\mathrm{K}-\mathrm{Cl}$ complexes to be incorporated into compounds of $\mathrm{Ca}$ and $\mathrm{Mg}$. The other two water environments are quite complex and there is no certain trend. It is necessary to combine the information derived from Fig. 5h. The graph (Fig. 5h) of $\mathrm{Cl}$ as a function of $\mathrm{Na}$ shows that the concentrations of $\mathrm{Cl}$ and $\mathrm{Na}$ ions vary from the shallow to deeper aquifers. This change is progressive, from the low $\mathrm{Na} / \mathrm{Cl}$ ratios of river water to very high $\mathrm{Na} / \mathrm{Cl}$ ratios typical of confined groundwater. The sodium present in both phreatic and confined groundwater is relatively higher, very likely a result of the hydrolysis of sodium-rich minerals (like labradorite to albite). Superficial phreatic groundwater has mostly higher $\mathrm{Cl}$ content, which is now explained by the sources of human-related activities like agricultural chemicals. Chloride ions can stay in solution in the soil and become concentrated by evaporation. They are then practically unavailable for dissolution into deeper groundwater during percolation, so that $\mathrm{Cl}$ in confined groundwater is not as strongly concentrated as in phreatic groundwater.

With regard to alkalis, the relative abundance of $\mathrm{SO}_{4}$ in groundwater of the area necessitates evaluation of its affinity for alkalis (Fig. 5g). Almost all the confined groundwater samples plot below the equal concentration line and river water samples above it. Normally, $\mathrm{SO}_{4}$ would prefer to be associated with $\mathrm{Ca}$ and alkalis. If any $\mathrm{Ca}$ or $\mathrm{Mg}$ would be left after consumption in bicarbonate complex, it may be available for the formation of $\mathrm{Ca}-\mathrm{SO}_{4}$ or $\mathrm{Mg}-\mathrm{SO}_{4}$ ionic species. For Han River water and some phreatic groundwater, $\mathrm{Na} / \mathrm{Cl}-\mathrm{SO}_{4}$ may be present as an aqueous species. This implies that the bulk of $\mathrm{SO}_{4}$ would be incorporated into alkali sulfates.

\section{Hydrochemical classification}

The main drinking water resource is shallow pore confined groundwater, pumped from wells with a depth of around $30 \mathrm{~m}$ and usually collectively supplied from waterworks. Hubei Environment Monitoring Station collected 62 samples from different waterworks in 2006 and their analysis is shown in a Piper diagram (Fig. 6), which is consistent with this study, confirming the shallow porous groundwater hydrochemistry characteristic in carbonate sediments. $\mathrm{HCO}_{3}{ }^{-}, \mathrm{Ca}^{2+}$ and $\mathrm{Mg}^{2+}$ play a dominating role, other than $\mathrm{Cl}^{-}$or $\mathrm{SO}_{4}{ }^{2-}$, and the major chemical type is $\mathrm{HCO}_{3}-\mathrm{Ca}-$ $\mathrm{Mg}$. Thus, major ion chemistry of the central Jianghan Plain is dominated by carbonate rock weathering, i.e., calcite and dolomite are responsible for water chemistry (Dalai et al. 2002), consistent with the fact that the study area is humid with abundant rainfall and the groundwater circulation and exchange are very active; so, the chemical type is mostly bicarbonate water. The TDS, i.e., the mineralization is generally bigger in groundwater than in
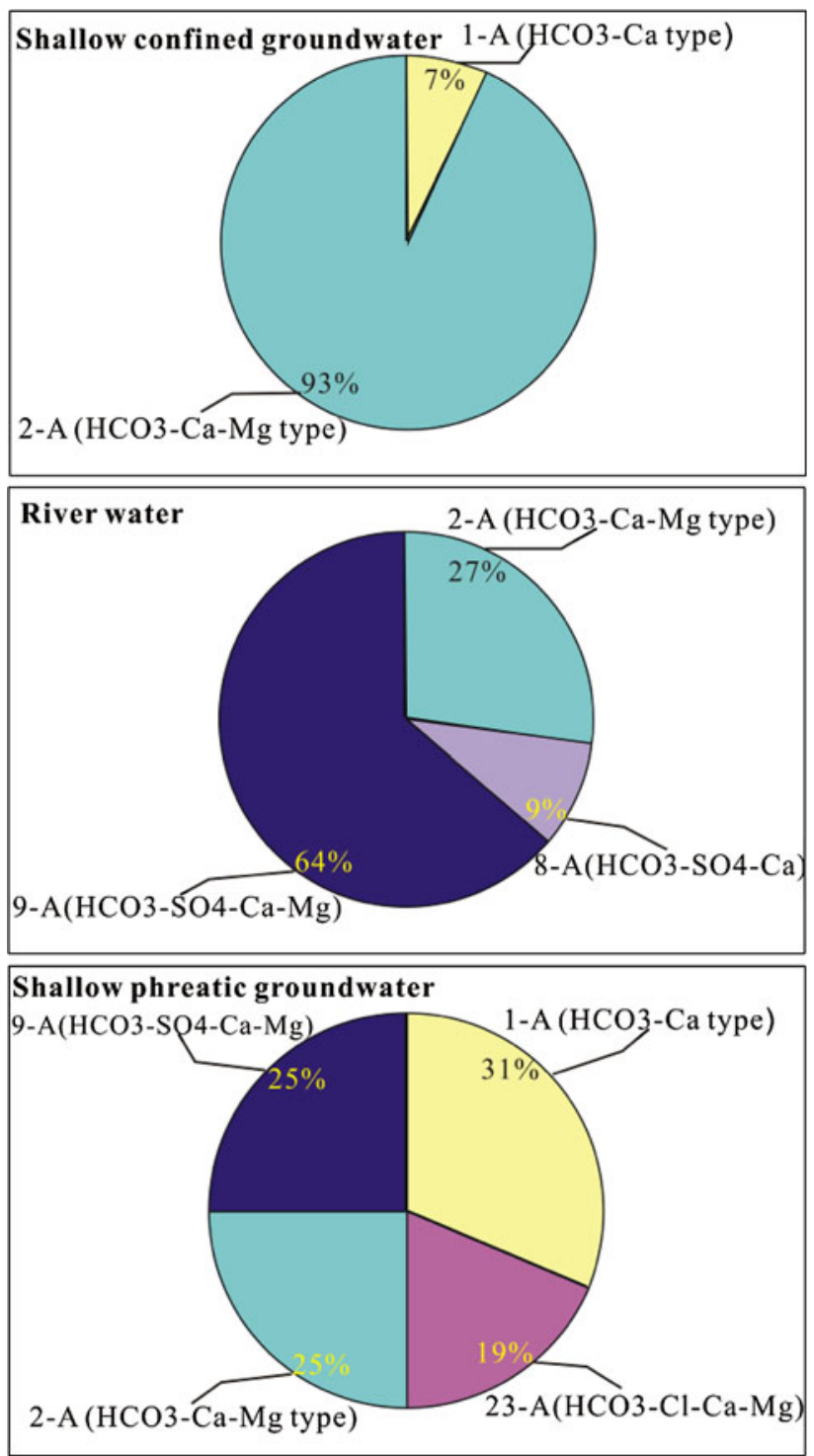

Fig. 7 Proportion diagram of hydrochemical classification of the water samples

surface water. However, the $\mathrm{SO}_{4}{ }^{2-}$ concentration is higher in river water than in groundwater, and is the highest in the rain sample. Therefore, it implies that sulfate has been dissolved from impurities and gases in the atmosphere while raining, and the river gets recharged by precipitation too.

The hydrochemical types (Fig. 7) of shallow confined groundwater include only $\mathrm{HCO}_{3}-\mathrm{Ca}$ and $\mathrm{HCO}_{3}-\mathrm{Ca}-\mathrm{Mg}$ with the latter constituting $93 \%$. This is quite typical for the aquifers in the study area, which are embedded in the geologically relatively open unconsolidated sediments. Calcite and dolomite dissolution are the dominant chemical processes involved in the generation of $\mathrm{HCO}_{3}-\mathrm{Ca}-\mathrm{Mg}$. These aquifer systems have short groundwater discharging flow path and the water-rock/soil interaction is intense, so 
Table 4 Parameters of water sampled at the same site in 2007 and 2008

\begin{tabular}{|c|c|c|c|c|c|c|c|c|c|}
\hline \\
\hline & $8-07$ & 99.13 & 22.76 & 17.34 & 1.36 & 505.32 & 3.58 & 1.09 & 397.93 \\
\hline & $8-08$ & 109.27 & 25.61 & 8.61 & 0.37 & 462.23 & 18.35 & 19.19 & 385.00 \\
\hline & \multicolumn{9}{|c|}{ Phreatic $\mathrm{gw}^{\mathrm{a}}$} \\
\hline & $34-07$ & 66.98 & 34.00 & 15.72 & 1.48 & 116.70 & 79.96 & 51.74 & 308.23 \\
\hline & $34-08$ & 83.48 & 25.79 & 17.83 & 2.37 & 244.39 & 52.48 & 82.45 & 378.00 \\
\hline & \multicolumn{9}{|c|}{ Han River } \\
\hline & $18-07$ & 49.24 & 13.49 & 4.56 & 2.72 & 131.57 & 11.84 & 42.53 & 190.17 \\
\hline & $18-08$ & 38.15 & 8.87 & 4.59 & 1.35 & 101.60 & 7.94 & 32.55 & 153.10 \\
\hline & \multicolumn{9}{|c|}{ Han River } \\
\hline & $35-07$ & 49.77 & 12.95 & 5.39 & 2.93 & 139.58 & 15.54 & 40.87 & 197.25 \\
\hline Groundwater (mo/l) & $35-08$ & 36.69 & 8.98 & 3.64 & 1.28 & 103.73 & 7.37 & 31.03 & 136.50 \\
\hline
\end{tabular}

they bear typical low mineralized hydrocarbonate water. For the river waters, the chemical types are $\mathrm{HCO}_{3}-\mathrm{Ca}-\mathrm{Mg}$, $\mathrm{HCO}_{3}-\mathrm{SO}_{4}-\mathrm{Ca}$ and $\mathrm{HCO}_{3}-\mathrm{SO}_{4}-\mathrm{Ca}-\mathrm{Mg}$, the last being $64 \%$. The dominating hydrochemical type of river water is $\mathrm{HCO}_{3}-\mathrm{SO}_{4}-\mathrm{Ca}-\mathrm{Mg}$ type, which is consistent with the type of rain and lake water that is caused by precipitation. Shallow phreatic groundwater has the most complicated mixed water types, $\mathrm{HCO}_{3}-\mathrm{Ca}(31 \%), \mathrm{HCO}_{3}-\mathrm{Cl}-\mathrm{Ca}-\mathrm{Mg}$ $(19 \%), \mathrm{HCO}_{3}-\mathrm{SO}_{4}-\mathrm{Ca}-\mathrm{Mg}(25 \%)$ and $\mathrm{HCO}_{3}-\mathrm{Ca}-\mathrm{Mg}$ (25\%). The bulk of the $\mathrm{HCO}_{3}$ may be assumed to have been acquired in the soil zone due to dissolution of $\mathrm{CO}_{2}$ and its transformation to $\mathrm{HCO}_{3}$ as a result of dissociation of $\mathrm{H}_{2} \mathrm{CO}_{3}$. Dissolution of calcium carbonate minerals in the area could also have contributed $\mathrm{HCO}_{3}$ to groundwater. Ideally, $\mathrm{Ca}$ and $\mathrm{Mg}$ might have been contributed through dissolution of carbonate minerals. Some $\mathrm{Mg}$ could have been added as a consequence of cation exchange in smectite-rich zones within clay beds (Umar and Alam 2012). Table 4 indicates that the water samples collected from the same site at different times show very similar major chemical compositions. Temporal fluctuations in groundwater chemistry are not apparent.

\section{Conclusions}

Waters in the central Jianghan Plain are slightly alkaline, except rain water which is slightly acidic. All waters have low TDS and mineralization, among which groundwater has a relatively wide range of TDS, while rain water has the lowest at $10.4 \mathrm{mg} / \mathrm{l}$ and high sulfate concentration. Groundwater samples are generally characterized as $\mathrm{HCO}_{3}-\mathrm{Ca}-\mathrm{Mg}$ water that interact with unconsolidated sediments. Phreatic groundwater is chemically distinct from deeper confined sources, suggesting minimal connection between them and interaction between phreatic groundwater and surface water or precipitation. The central plain is typically carbonate, and some abnormal high values for $\mathrm{NO}_{3}{ }^{-}, \mathrm{Cl}^{-}$and $\mathrm{SO}_{4}{ }^{2-}$ indicate anthropogenic impacts. As, $\mathrm{Si}, \mathrm{Mn}, \mathrm{S}$, iron and $\mathrm{NO}_{3}{ }^{-}$show spatial variation in the study area. $\mathrm{Mn}, \mathrm{NO}_{3}{ }^{-}$and As contents in groundwater exceed the WHO guideline standards in some regions; high content $\mathrm{Mn}$ and As are attributed to geological reasons which cause their release from matrix rocks. The local people should ensure some pretreatment of their drinking water, but special attention should be paid to the high $\mathrm{NO}_{3}{ }^{-}$concentrations caused by agriculture activities. Diffuse pollution due to land use practices has become a key contributor to the declining water quality, and pollution prevention requires a better understanding of water quality and the impact by land use and land cover in the basin. Further isotopic studies are needed to ascertain the groundwater recharge processes.

\section{References}

Acharyya SK, Lahiri S, Raymahashay BC, Bhowmik A (2000) Arsenic toxicity of groundwater in parts of the Bengal basin in India and Bangladesh: the role of Quaternary stratigraphy and Holocene sea-level fluctuation. Environ Geol 39:1127-1137

Bhattacharya P, Chatterjee D, Jacks G (1997) Occurrence of arseniccontaminated groundwater in alluvial aquifers from the Bengal Delta Plain, Eastern India: options for a safe drinking water supply. Water Resour Dev 13:79-92

Carpenter SR, Caraco NF, Correll DL, Howarth RW, Sharpley AN, Smith VH (1998) Non-point pollution of surface waters with phosphorus and nitrogen. Ecol Appl 8:559-568

Chen J, Gao X, He, Xia X (2000) Nitrogen contamination in the Yangtze River system, China. J Hazard Mater 73(2):107-113

Chen J, Wang F, Xia X, Zhang L (2002) Major element chemistry of the Changjiang (Yangtze River). Chem Geol 187:231-255

Dalai TK, Krishnaswami S, Sarin MM (2002) Major ion chemistry in the headwaters of the Yamuna River system: chemical 
weathering, its temperature dependence and $\mathrm{CO}_{2}$ consumption in the Himalaya. Geochim Cosmochim Acta 66:3397-3416

Even E, Wang Y, Cao L, Zhou Y, Shao Y, Zwhalen F (2011) Hydrogeochemistry of As-contaminated groundwater at Shahu villages of Jianghan Plain, central China. Environmental Earth Sciences (in press)

Harvey CF, Swartz CH, Badruzzaman ABM, Keon-Blute N, Yu W, Ali MA, Jay J, Beckie R, Niedan V, Brabander D, Oates PM, Ashfaque KN, Islam S, Hemond HF, Ahmed MF (2002) Arsenic mobility and groundwater extraction in Bangladesh. Science 298:1602-1606

Harvey CF, Swartz CH, Badruzzaman ABM, Keon-Blute N, Yu W, Ali MA, Jay J, Beckie R, Niedan V, Brabander D, Oates PM, Ashfaque KN, Islam S, Hemond HF, Ahmed MF (2005) Groundwater arsenic contamination on the Ganges Delta: biogeochemistry, hydrology, human perturbations, and human suffering on a large scale. Compt Rend Geosci 337:285-296

Hem JD (1989) Study and interpretation of the chemical characteristics of natural water (3rd. Ed). US Geological survey watersupply paper \# 2254, p 363

Hu M, Stallard RF, Edmond JM (1982) Major ion chemistry of some large Chinese rivers. Nature 298:550-553

HHT (Hubei hydrogeology team) (1976) Hydrogeological map notice: Mianyang (H-49-18), regional hydrogeological investigation report, Wuhan, December 1 (in Chinese)

Li S, Xu Z, Cheng X, Zhang Q (2008) Dissolved trace elements and heavy metals in the Danjiangkou Reservoir. China Environ Geol 55:977-983

Li S, Liu W, Gu S, Cheng X, Xu Z, Zhang Q (2009) Spatio-temporal dynamics of nutrients in the upper Han River basin, China. J Hazard Mater 162(2):1340-1346

Liu S, Zhang J, Chen H, Wu Y, Xiong H, Zhang Z (2003) Nutrients in the Changjiang and its tributaries. Biogeochemistry 62(1):1-18

Mackenzie F (1998) Our changing planet an introduction to earth system science and global environmental change. Prentice Hall, Englewood Cliffs, p 486

Mallick S, Rajgopal NR (1995) Groundwater development in the arsenic affected alluvial belt of West Bengal-some questions. Curr Sci 70:956-958

McArthur JM, Ravenscroft P, Safiullah S, Thirlwall MF (2001) Arsenic in groundwater: testing pollution mechanisms for aquifers in Bangladesh. Water Resour Res 37:109-117
McArthur JM, Banerjee DM, Hudson-Edwards KA, Mishra R, Purohit R, Ravenscroft P, Cronin A, Howarth RJ, Chatterjee A, Talukder T, Lowry D, Houghton S, Chadha D (2004) Natural organic matter in sedimentary basins and its relation to arsenic in anoxic groundwater: the example of West Bengal and its worldwide implications. Appl Geochem 19:1255-1293

Mukherjee A, Von Brössen M, Scanlon BR, Bhattacharya P, Fryar AE, Hasan MA, Ahmed KM, Jacks G, Chatterjee D, Sracek O (2008) Hydrogeochemical comparison and effects of overlapping redox zones on groundwater arsenic near the western (Bhagirathi sub-basin, India) and eastern (Meghna sub-basin, Bangladesh) of the Bengal basin. J Contam Hydrol 99(1-4):31-48. doi:10.1016/j.jconhyd.2007.10.005

Mukherjee A, Fryar AE, Thomas WA (2009) Geologic, geomorphic and hydrologic framework and evolution of the Bengal basin. India and Bangladesh. J Asian Earth Sci 34:227-244

Nickson R, McArthur JM, Ravenscroft P, Burgess WG, Rahman M (1998) Arsenic poisoning of groundwater in Bangladesh. Nature 395:338

Nickson R, McArthur JM, Ravenscroft P, Burgess WG, Ahmed M (2000) Mechanism of arsenic release to groundwater, Bangladesh and West Bengal. Appl Geochem 15:403-411

Ravenscroft P, McArthur JM, Hoque B (2001) Geochemical and palaeohydrological controls on pollution of groundwater by arsenic. In: Chappell WR, Abernathy CO, Calderon RL (eds) Arsenic exposure and health effects IV. Elsevier Science, Oxford, pp 53-77

Umar R, Alam F (2012) Assessment of hydrogeochemical characteristics of groundwater in parts of Hindon-Yamuna interfluves region, Baghpat District, Western Uttar Pradesh. Environ Monit Assess 184:2321-2336

WHO (1994) Guidelines for drinking water quality, vol 1. WHO, Geneva

WHO (1996) Guidelines for drinking-water quality, 2nd edn. vol. 2 Health criteria and other supporting information, Geneva, Switzerland, pp 940-949

Zheng Y, Stute M, Van Geen A, Gavrieli I, Dhar R, Simpson HJ, Schlosser P, Ahmed KM (2004) Redox control of arsenic mobilization in Bangladesh groundwater. Appl Geochem 19:201-214 